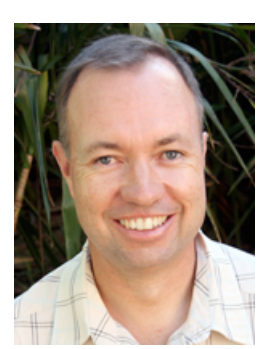

\title{
SOIL GOVERNANCE IN THE AGRICULTURAL LANDSCAPES OF NEW SOUTH WALES, AUSTRALIA
}

\section{Ashley A Webb}

NSW Department of

Primary Industries,

Australian Centre for

Agriculture and Law,

University of New England

Australia

\author{
Georgina L Kelly \\ NSW Department of Primary \\ Industries \\ School of Biological, \\ Environmental, Earth Sciences \\ University of New South Wales \\ Australia
}

\section{Warwick J Dougherty \\ NSW Department of Primary \\ Industries \\ Parramatta \\ Australia}
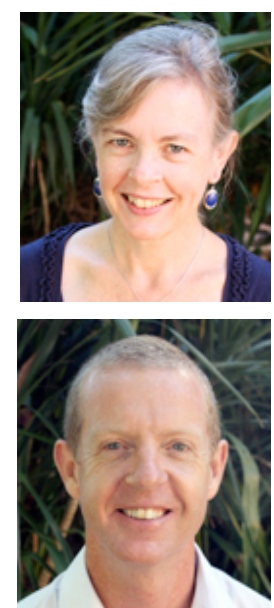

Soil is a valuable natural resource. In the state of New South Wales, Australia, the governance of soil has evolved since Federation in 1901. Following rapid agricultural development, and in the face of widespread soil degradation, the establishment of the Soil Conservation Service marked a turning point in the management of soil. Throughout the $20^{\text {th }}$ century, advances in knowledge were translated into evolving governance frameworks that were largely reactionary but saw progressive reforms such as water pollution legislation and case studies of catchmentscale land and vegetation management. In the $21^{\text {st }}$ century, significant reforms have embedded sustainable use of agricultural soils within catchment- and landscape-scale legislative and institutional frameworks. What is clear, however, is that a multitude of governance strategies and models are utilised in NSW. No single governance model is applicable to all situations because it is necessary to combine elements of several different mechanisms or instruments to achieve the most desired outcomes. Where an industry, such as the sugar industry, has taken ownership of an issue such as acid sulfate soil management, self-regulation has proven to be extremely effective. In the case of co-managing agricultural soils with other landuses, such as mining, petroleum exploration and urban development, regulation, compliance and enforcement mechanisms have been preferred. Institutional arrangements in the form of independent commissioners have also played a role. At the landscape or total catchment level, it is clear that a mix of mechanisms is required. Fundamental, however, to the successful evolution of soil governance is strategic investment in soil research and development that informs the ongoing productive use of agricultural landscapes while preventing land degradation or adverse environmental effects.

\section{Introduction}

Soil is a valuable natural resource, and in the state of New South Wales (NSW), Australia, soil makes a significant contribution to the economy. ${ }^{1}$ Agricultural production in NSW is worth $\$ 15.4$ billion per annum, ${ }^{2}$ the bulk of which is underpinned by soil. In the past, this contribution has come at some cost to soil health due to limited knowledge and information, mismanagement and poor practices.

NSW has a diverse range of soils, from those shallow and low in natural fertility, to deep and highly productive. Inappropriate management, however, has led to many soils being degraded through processes such as erosion, acidification, nutrient depletion, contamination, compaction, loss of soil carbon and soil structure, and salinisation; all soil types are, potentially, at risk of degradation. ${ }^{3}$ This degradation reduces the productive capacity of soils and can be difficult and costly to remediate. Sustainable soil use, management and conservation are critical in the achievement of economic, environmental and social goals for NSW. ${ }^{4}$

\footnotetext{
NSW Department of Primary Industries (DPI), Position Statement on Soils (2013).

Talina Drabsch, Economic Indicators NSW: Statistical Indicators 1/13 (NSW Parliamentary Library, January 2013).

State of the Environment Committee, 'State of the Environment Report 2011' (Independent report to the Australian

Government Minister for Sustainability, Environment, Water, Population and Communities, DSEWPaC, 2011) ('SoE 2011').

DPI, above $n 1$.
} 
The Commonwealth Government has an objective to double food production in Australia by 2050 but the area of available arable land is expected to decline. ${ }^{5}$ Competition for land and soil resources to meet food, timber, fibre, mining and energy needs are increasing. Challenges in soil management for NSW include improving the management of soil - and thus plant nutrition to optimise input efficiencies - and improving the capture and use of soil water.

Production landscapes must be profitably managed. However, management must include the prevention of unwanted environmental and social off-site effects to ensure sustainable productivity over the long term. Soils, therefore, should be managed to store more carbon and deliver agricultural products and ecosystem services, such as clean air and water. ${ }^{6}$ As with other natural resources, such as water, the governance of productive soils is not straightforward. This is due to changing perspectives of the value of soils as well as the evolution and complexity of natural resource legislation, policy and institutional frameworks that, over time, have increasingly embedded soil governance within the context of managing other resources, such as water and vegetation. For the purposes of this paper we treat laws, regulations and governance as three points on a continuum where laws are promulgated by parliaments and interpreted by the courts; regulations are more flexible and can include market based mechanisms; and governance involves any number of mechanisms or strategies that do not necessarily privilege the state 'in a world of diffused power and responsibility'. ${ }^{7}$

This paper aims to describe the historical and contemporary governance of agricultural soils in NSW by, first, discussing soil conservation during the $20^{\text {th }}$ century and then evaluating specific case studies focussed on differing models of governance. Case studies include: reforms for sustainable agriculture; the protection of productive soils from subdivision threats; the co-existence of agriculture and mining, petroleum exploration and extractive industries; management of diffuse source pollution; management of acid sulfate soils; and initiatives to manage land and vegetation within landscape- and catchment-contexts. Further, the paper identifies the role of research and development in framing sound soil governance and the most effective initiatives to inform future soil management policy based on an evaluation of case studies. While a number of components of soil policy are being actively considered by governments in all the eastern Australian states, it may be pre-emptive to discuss the implications of unpublished and emerging policy developments. Therefore, the focus in this paper is on published and implemented work to date.

\section{Soil conservation: A historical perspective}

In the early years of Federation in Australia, there was little legislation dealing directly with soil management. Much of the early legislation dealing with land management revolved around leases granted by the Crown in the early 1900s when primary industries were expanding in NSW. ${ }^{8}$ Rather than conserving soil resources, the focus was on the requirement for lessees to carry out 'improvements' to the land, such as cultivating it, ${ }^{9}$ fencing areas, ${ }^{10}$ improving the water supply, and destroying rabbits, wild dogs and other feral animals so as to increase the carrying capacity of the land. ${ }^{11}$

In recognition of widespread degradation of soil resources that was evident by 1935 , the State Government established an Erosion Committee. ${ }^{12}$ The Committee reported widespread soil erosion, especially on grazing and farming land. The NSW Parliament passed the Soil Conservation Act 1938 (NSW) and this established the Soil Conservation Service (SCS), ${ }^{13}$ an agency whose remit was to conserve soil resources, mitigate erosion and

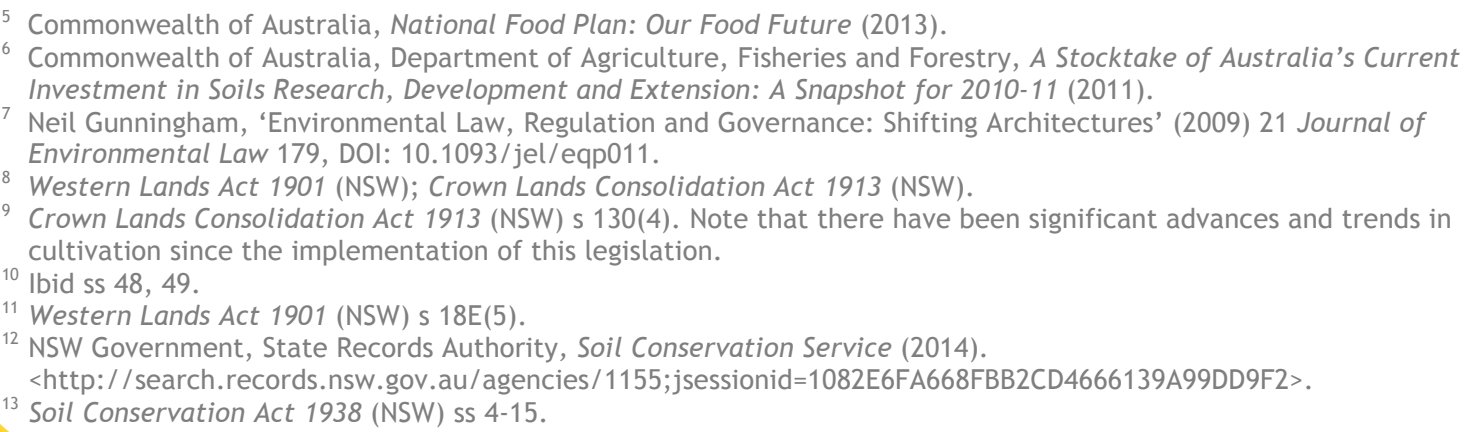


land degradation, and conserve water resources. ${ }^{14}$ Unfortunately, however, little activity occurred during the early years of the SCS, predominantly due to the onset of World War II. ${ }^{15}$

After the War, the SCS established a series of research stations to conduct research on soil conservation and erosion mitigation. ${ }^{16}$ Soil conservation demonstration sites were also introduced on private land and plant nurseries were established. ${ }^{17}$ From 1947, the locations from which the SCS operated were expanded. ${ }^{18}$ The role of the SCS was also expanded in $1947^{19}$ to enable financial and technical assistance to be provided to landholders. ${ }^{20}$ Assistance was provided in the form of loans issued by the Rural Bank, ${ }^{21}$ which exists today as the Rural Assistance Authority. ${ }^{22}$ The Nottingleigh Soil Conservation Research Station was established northwest of Hay to examine wind erosion, ${ }^{23}$ while further experiments were conducted in the western division of the state, ${ }^{24}$ into issues such as the death of the Mulga in the Western Darling region. ${ }^{25}$ In 1950/1951 another expansion of the SCS area of operation occurred. ${ }^{26}$ Another post-war initiative was the War Service Land Settlement Scheme. ${ }^{27}$

Following widespread flooding and consequent erosion in the Hunter Valley, ${ }^{28}$ the State Government passed the Hunter Valley Conservation Trust Act 1950 (NSW) to establish the Hunter Valley Conservation Trust. This body was charged with restricting certain activities upon the lands of the Hunter Valley and was funded by rates paid by the Valley's landowners. The Commissioner of the SCS was a trustee and was able to investigate and make recommendations on erosion control works required in the Hunter Valley, to be funded by the Trust. ${ }^{29}$ Similarly, under s10 of the Soil Conservation Act 1938 (NSW) entire valley projects were commenced in 1965, usually by agreement between the SCS and landholders; where needed, the projects were financed by the SCS. Such projects typically involved programs of improvement, including the application of fertilisers, fencing, pasture improvement and soil conservation works. ${ }^{30}$ In many ways these projects were a pre-curser to the more recent Catchment Action Plans administered by Catchment Management Authorities, the latter now part of Local Land Services. ${ }^{31}$

The SCS ceased to exist as a separate government agency in 1991, when it was incorporated into the Department of Conservation and Land Management. ${ }^{32}$ It was later restructured and made part of the

${ }^{14}$ Soil Conservation Act 1938 (NSW) s 4C.

${ }^{15}$ SCS noted that 'suitably qualified manpower, major plant and materials generally have been in extremely short supply during the war years and in the immediate post-war period'; SCS, 'Annual Report of the Soil Conservation Service of New South Wales for the year ended 30 June 1946' (Joint Volumes of Papers Presented to the Legislative Council and Legislative Assembly, Vol 1, 1947-48) 69.

${ }^{16}$ Soil Conservation Act 1938 (NSW) s 6. These stations, established in the 1940s, were located at Cowra, Wellington, Wagga, Inverell and Gunnedah as centres of soil conservation and erosion control.

${ }^{17}$ Nurseries were established at Keepit Dam near Tamworth, and at Wellington, Wagga Wagga, Gunnedah and Inverell.

${ }^{18}$ New offices were located at Tamworth, Orange, Scone, Goulburn, Broken Hill, Camden, Condobolin, Griffith, Manilla, Tumut and Young; SCS, (1947-48) aobven n 15, 73. Further office locations were opened up during 1948/1949 in Glen Innes, Barraba, Coonabarabran, Narrabri, Cootamundra, Mudgee, Bathurst, Dubbo, Parkes and Albury.

${ }^{19}$ Soil Conservation (Amendment) Act 1947 (NSW).

${ }^{20}$ Soil Conservation Act 1938 (NSW) pt 4A.

${ }^{21}$ SCS, above n 15.

${ }^{22}$ Rural Assistance Act 1989 (NSW).

${ }^{23}$ SCS, 'Annual Report of the Soil Conservation Service of New South Wales for the Year Ended 30 June 1949' (Joint Volumes of Papers Presented to the Legislative Council and Legislative Assembly, vol 1, 1948-49-50).

${ }^{24}$ Crown Lands Act 1989 (NSW) s 4(2A).

${ }^{25}$ SCS, (1948-49-50), above n 23.

${ }^{26}$ New offices were opened in Kempsey, Yass, Singleton, Denman, Merriwa, Muswellbrook and Murrurundi; SCS, 'Annual Report of the Soil Conservation Service of New South Wales for the Period of Two Years - From 1 July 1949 to 30 June 1951' (Joint Volumes of Papers Presented to the Legislative Council and Legislative Assembly, vol 1, 1952-53).

${ }^{27}$ This enabled the Lands Department to acquire some 785 estates and subsequently sub-divide them into 2609 blocks for the benefit and resettlement of returned servicemen; War Service Land Settlement Act 1941 (NSW). Where necessary, by arrangement with the Lands Department, the SCS assessed each property and provided detailed recommendations, setting out measures required to control or prevent further erosion: SCS, 'Annual Report of the Soil Conservation Service of New South Wales for the year ended 30 June 1968' (Joint Volumes of Papers Presented to the Legislative Council and Legislative Assembly, vol 1, 1968-69 ) 604

${ }^{28}$ A F Reddoch, 'River Control Work in the Non-Tidal Section of the Hunter River and its Tributaries' (1957) 29 Journal of the Institute of Engineers, Australia 241; W H Shattock, 'A Review of River Improvement Works on Non-Tidal Streams in New South Wales' (1966) 38 Journal of the Institute of Engineers, Australia 275.

${ }^{29}$ Hunter Valley Conservation Trust Act 1950 (NSW) s 12.

${ }^{30}$ SCS, 'Annual Report of the Soil Conservation Service of New South Wales for the year ended 30 June 1971' (Joint Volumes of Papers Presented to the Legislative Council and Legislative Assembly, vol 1, 1971-72) 734.

${ }^{31}$ Catchment Management Authorities Act 2003 (NSW), as repealed by Local Land Services Act 2013 (NSW) s 210(b).

${ }^{32}$ Department of Conservation and Land Management, 'Annual Report for the Year Ended 1992' 9. 
Department of Land and Water Conservation. In 2003 it became part of the Department of Primary Industries (DPI) and has a commercial focus employing 130 staff operating from 30 centres across the state. ${ }^{33}$

\section{Contemporary soil governance in agricultural landscapes}

Despite several key reforms in recent decades, the governance of soil in NSW remains somewhat disparate, scattered across a range of agencies, strategies and legislative instruments. There is no unifying up-to-date soils policy; nevertheless, there are some progressive initiatives that indicate this could be developed in the near future. A number of NSW agencies contribute to, or have responsibility for, legislation that influences soil management in NSW. Public soil expertise and responsibilities reside within NSW DPI and the Office of Environment and Heritage (OEH). Within NSW, DPI Agriculture has a large research and development (R\&D) nit and other expertise and extension responsibilities sits within the Local Land Services, and Lands and Natural Resources branch. The Department of Infrastructure and Planning and the Environment Protection Authority (EPA) also have responsibilities for legislation relating to soil management in NSW.

The original NSW Soils Policy was released in 1987 as a component policy under the Total Catchment Management (TCM) Policy umbrella. ${ }^{34}$ In the 1990 s the emphasis was on the native vegetation reforms and 'protected lands' provisions from the Soil Conservation Act 1938 (NSW) (and their transfer into the native vegetation legislation). Since 1987, the need to review and update the soil policy framework has been considered by Government on several occasions. However, the approach to date has been to include soils in broader natural resource management polices rather than as a stand-alone issue. For example, the 13 statewide targets adopted in 2004 and still in place include two soils-specific targets. ${ }^{35}$

This précis of the policy and legislation that impacts soil management objectives and functions demonstrates the complexity and need for a whole-of-government approach to modern soils management, and a strategy to deliver investments and actions for a modern, collaborative approach to soils management. The NSW DPI Soils Statement was recently published and one of the initiatives identified therein is to focus on developing a revitalised soils policy framework for the NSW Government. ${ }^{36}$

\section{Case studies of soil governance}

In natural resource management, there is much debate regarding which are the most appropriate models of governance and which combination of the many available instruments and strategies will be most effective. ${ }^{37}$ With specific reference to soil, there are many available instruments and strategies. ${ }^{38}$ Several case studies presented in this section illustrate how agricultural soil governance is delivered in NSW. It is not practical to provide an example of each of the instruments and strategies potentially available. The case studies outlined demonstrate which instruments and strategies are most often used, pointing either to their success or the potential for complimentary new approaches to increase their success.

\section{Sustainable agriculture}

The state of NSW has a policy for sustainable agriculture, which, in essence, aims to ensure that the agricultural industries of NSW contribute to the state's productivity and economy while protecting 'the State's biological and physical resource base' and preventing 'adverse on-site and off-site impacts on the environment'. ${ }^{39}$ The policy recognises that past agricultural activities have, in some instances, had adverse impacts on the quality of the land resources, especially evident in soil erosion, dryland salinity and soil

33 DPI, Soil Conservation Service (2015) <http: / /www.scs.nsw.gov.au/about-scs>

34 NSW Government, State Soils Policy, (1987); NSW Government, Total Catchment Policy (1987).

${ }^{35}$ NSW Government, NSW 2012: A Plan to Make NSW Number One (September 2011).

${ }^{36} \mathrm{DPI}$, above $\mathrm{n} 1$.

${ }^{37}$ Stephen Dovers, 'A Framework for Scaling and Framing Policy Problems in Sustainability' (1995) 12 Ecological Economics 93 , 104, DOI: 10.1016/0921-8009(94)00042-T

${ }^{38}$ State Extension Leaders Network, Enabling Change in Rural and Regional Australia: The Role of Extension in Achieving Sustainable and Productive Futures (University of Tasmania, 2006). Strategies and instruments include: regulation, enforcement and compliance; direct investment; covenants and memoranda of understanding; common law, duty of care, stewardship; formal agreements; research and development; monitoring and evaluation; assessment procedures; selfregulation; quality assurance processes, environmental management systems and eco-labelling; public relations, marketing and advertising; formal education and training; suasion; extension; participatory approaches; economic incentives; conditionalities or cross-compliance; institutional arrangements; change other policies; and reasoned inaction. ${ }^{39}$ NSW Agriculture, Policy for Sustainable Agriculture in New South Wales (1998) 1. 
acidification. Furthermore, it acknowledges that, due to very slow rates of soil formation and the basic importance of soils in underpinning agricultural wealth, the state's soil should be considered as a nonrenewable resource.

Key strategies within the Policy for Sustainable Agriculture relevant to soil include:

- Developing awareness of the need to minimise adverse off-site impacts of land management practices;

- Improving awareness and assessment of the causes, symptoms and impacts of soil degradation;

- Developing and adopting management practices and farming systems that conserve and enhance the health of soil resources;

- Using fertilisers to achieve maximum benefits in replacing nutrients used to produce agricultural products, with minimal adverse impact on the environment;

- $\quad$ Further developing and managing the agricultural use of organic wastes from urban, industrial and agricultural activities so that the components of waste are effectively used by plant growth or sustainably assimilated by the soil at the application site;

- Using Total Catchment Management and Landcare principles and plans to ensure that the off-site impacts of agriculture are considered and managed effectively;

- Ensuring the equitable and efficient allocation of land and other natural resources between agriculture and other sectors of the community;

- Ensuring landuse planning is undertaken to avoid conflict that may jeopardise agriculture's sustainability; and

- Ensuring enactment of environmental impact assessment procedures that result in the sustainable development of agriculture.

The Policy itself cannot enforce the majority of these strategies. However, in the following sections it will become evident that many of these strategies have become embedded within other governance mechanisms. In terms of models of soil governance, the Policy for Sustainable Agriculture is largely a combination of R\&D and extension, which collectively aim to increase knowledge and contribute to the development and adoption of changes in practice. DPI and previous departments of agriculture in NSW have been effectively conducting R\&D and extension for many decades. However, as will be discussed below under the heading 'Catchmentscale land and vegetation management', much of the soils extension role is now conducted by the Local Land Services. Nevertheless, the Policy for Sustainable Agriculture also points to other models and strategies, such as regulation, enforcement and compliance, and assessment procedures, which are enacted by other agencies, as discussed below.

\section{Protecting productive soils from sub-division threats}

In NSW, environmental planning instruments can be made at either a state, regional or local level. ${ }^{40}$ Arguably, the most important of these for protecting agricultural land at a state level is the State Environmental Planning Policy ('SEPP') (Rural Lands) 2008 (NSW). The SEPP Rural Lands has several aims but those most relevant to protecting the agricultural soil resource base are:

- To facilitate the orderly and economic use and development of rural lands for rural and related purposes; ${ }^{41}$

- To implement measures designed to reduce landuse conflicts; ${ }^{42}$ and

- To identify state significant agricultural land for the purpose of ensuring the ongoing viability of agriculture on that land, having regard to social, economic and environmental considerations. ${ }^{43}$

The SEPP Rural Lands applies to the entire state with the exception of city council areas and local government areas predominantly at the peri-urban fringe of the greater Sydney region, ${ }^{44}$ even though, in some cases agriculture is a substantial landuse within the rateable area of the peri-urban fringe. The SEPP deals with

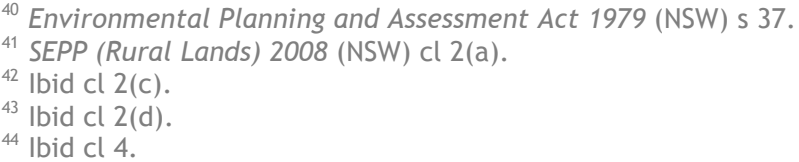


planning principles relevant to rural land, such as subdivision of land for agricultural purposes and also for rural dwellings. ${ }^{45}$ However, arguably, the greatest potential value of the SEPP in terms of protecting productive agricultural land is the provisions relating to the identification of 'State significant agricultural land' which can be of state or regional significance. ${ }^{46}$ In protecting such land, the SEPP requires an assessment to determine if the land is in demand for uses that are incompatible with agriculture, and if the protection will result in a public benefit. ${ }^{47}$ To date, however, no state significant agricultural land has been identified in NSW. ${ }^{48}$ This does raise a question about whether or not there has yet been effective implementation of the SEPP. Note that state significant agricultural land is distinguished from Biophysical Strategic Agricultural Land (BSAL), which is discussed further in the next section.

Despite there being no identified state significant agricultural land in NSW, some local environmental plans (LEPs) make provisions for the protection of agricultural land. As an example, the Liverpool Plains of NSW, which comprise some of the most fertile soils in the state, have long been recognised as being highly productive. ${ }^{49}$ To this end a LEP has been developed for the Liverpool Plains Shire Council area. ${ }^{50}$ With regard to protecting the soils resource, the LEP aims to 'encourage the proper management of the natural and manmade resources of the Liverpool Plains' by protecting, enhancing or conserving productive agricultural land, timber, minerals, soils, water and other natural resources. ${ }^{51}$ It also aims to 'provide a secure future for agriculture by expanding Liverpool Plains' economic base and minimising the loss or fragmentation of productive agricultural land'; 'minimise landuse conflict';" and 'ensure that development has regard to the capability of the land'. ${ }^{4}$

Within the Liverpool Plains LEP, the Shire's area is partitioned into various landuse zones, each with specific objectives and permitted (with or without consent) or prohibited development activities. ${ }^{55}$ With regard to agriculture there are four 'Rural' zones: 'Primary Production', 'Forestry', 'Village' and 'Transition'. The objectives of the Primary Production Zone are to: 'encourage sustainable primary industry production by maintaining and enhancing the natural resource base'; 'encourage diversity in primary industry enterprises and systems appropriate for the area'; 'minimise the fragmentation and alienation of resource lands'; and 'minimise conflict between landuses within this zone and landuses within adjoining zones'. ${ }^{56}$ As expected, within this zone, activities such as extensive agriculture, roads, farm buildings, environmental protection works and water supply systems are permitted without consent. Consent, however, is required for more intensive activities such as intensive livestock agriculture, intensive plant agriculture, aquaculture, extractive industries, dwelling houses and animal boarding establishments. Prohibited activities include hotel or motel accommodation, sawmill or log processing works, and serviced apartments.

The Liverpool Plains LEP defines extensive agriculture as including: 'the production of crops or fodder (including irrigated pasture and fodder crops) for commercial purposes'; 'the grazing of livestock for commercial purposes'; 'beekeeping'; and pasture-based dairies. ${ }^{57}$ By contrast, intensive livestock agriculture is defined as 'the keeping or breeding, for commercial purposes, of cattle, poultry, pigs, goats, horses or other livestock that are fed wholly or substantially on externally-sourced feed'. This includes restricted dairies, feedlots, piggeries and poultry farms. Similarly, intensive plant agriculture includes 'the cultivation of irrigated crops for commercial purposes (other than irrigated pasture or fodder crops)', horticulture, turf farming and viticulture. ${ }^{58}$

The primary production landuse zone of 'Forestry' aims to enable development for forestry purposes or development that is compatible with forestry landuses. ${ }^{59}$ Essentially this restricts activities without consent to

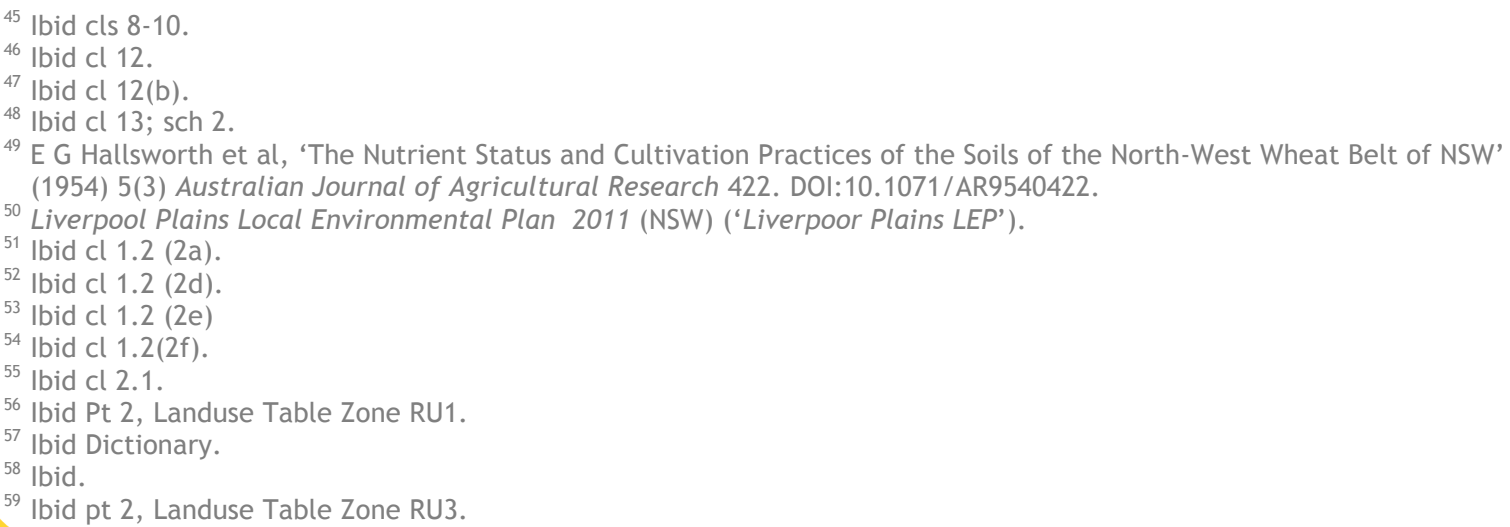


beekeeping, roads and authorised forestry activities. ${ }^{60}$ The 'Village' landuse zone aims, among other things, to 'provide for a range of landuses, services and facilities that are associated with a rural village', ${ }^{61}$ while the objectives of the 'Transition' landuse zone are to 'protect and maintain land that provides a transition between rural and other landuses of varying intensities or environmental sensitivities' and 'minimise conflict between landuses within this zone and landuses within adjoining zones'. ${ }^{62}$

In addition to defining the activities that can occur within each landuse zone, an important feature of the LEP is its objectives with regard to rural subdivision. Across the Primary Production landuse zone, minimum lot sizes have been defined and no subdivision can occur if a resulting lot will be smaller in area than the set limit. ${ }^{63}$ These zoning and minimum lot size restrictions demonstrate that, in NSW, effective instruments are available to provide general preservation of the soils resource by ensuring that productive soils are zoned, where possible, for agricultural uses and that farm areas are large enough to enable agricultural enterprises to remain economically viable.

\section{Co-existence of agricultural and mining activities}

Mining, petroleum production and extractive industries are major employers in NSW, supporting more than 155 000 jobs. Their contribution to the state's economy in $2012 / 13$ was $\$ 26.6$ billion, equivalent to 5.8 per cent of the gross state product. ${ }^{64}$ The largest proportion of direct full-time employment of resident employees occurs in the Hunter region, followed by the Central West and Illawarra regions. Indeed, in 2012/13 mining accounted for 35.8 per cent of the Hunter region's gross regional product. ${ }^{65}$ However, mining, petroleum production and extractive industries often occur on or adjacent to productive agricultural enterprises and, therefore, represent direct competition for access to, or exploitation of, the state's soil resources.

In part, to balance competition between mining and other landuses, the NSW government enacted the SEPP (Mining, Petroleum Production and Extractive Industries) 2007 (NSW). One of the aims of the SEPP is to establish a 'gateway process' for certain mining and petroleum (oil and gas) development. ${ }^{66}$ This is to: 'recognise the importance of agricultural resources'; 67 'ensure protection of strategic agricultural land and water resources'; 68 'ensure a balanced use of land by potentially competing industries'; ; $^{69}$ and 'provide for the sustainable growth of mining, petroleum and agricultural industries' ${ }^{70}$

The SEPP allows for mineral exploration and fossicking, as well as petroleum exploration, ${ }^{71}$ but requires development consent for underground mining, mining, extractive industry, drilling or operating petroleum exploration wells, or petroleum production on land 'where development for the purposes of agriculture or industry may be carried out'. ${ }^{72}$ Additionally, the SEPP was amended in 2013 to prohibit coal seam gas development in certain exclusion zones; namely in 'coal seam gas exclusion' zones and 'buffer' zones. ${ }^{73}$ Coal seam gas exclusion zones include areas of land within residential zones, future residential growth areas, 'additional rural village land' and 'critical industry cluster land'. According to the Strategic Regional Landuse Policy, the two critical industry clusters identified to date are the equine and viticulture industries in the upper Hunter Valley region. These account for 4.4 per cent and 9.7 per cent of the area of the Upper Hunter region respectively. ${ }^{74}$

BSAL, ${ }^{75}$ defined as land with high quality soil and water resources capable of sustaining high levels of productivity, totals 2.8 million hectares across NSW. ${ }^{76}$ In NSW a development application for consent to mining or petroleum development on land mapped as BSAL must be accompanied by either a 'site verification

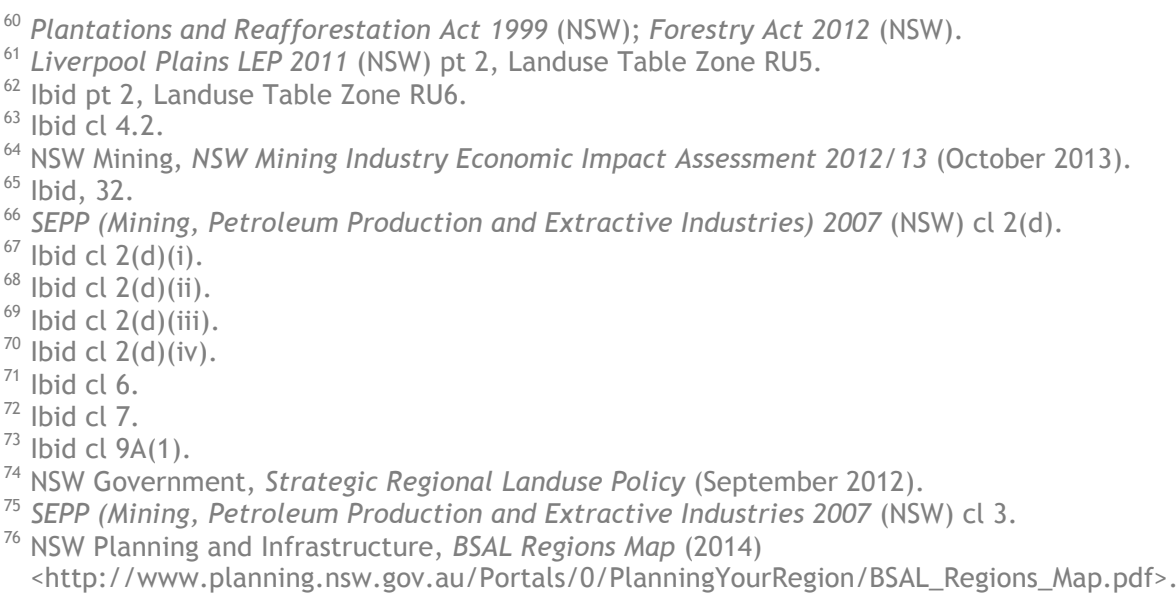


certificate' or a 'gateway certificate'. ${ }^{77}$ A site verification certificate is, in effect, a certificate that can be issued by the Director-General ${ }^{78}$ of the NSW Department of Trade and Investment, Regional Infrastructure and Services to certify that the land to be developed is not BSAL. ${ }^{79}$ An application for a gateway certificate is to be submitted to the Gateway Panel when the proposed mining or petroleum development is to be carried out on BSAL. ${ }^{80}$ The Gateway Panel is an independent panel of experts in the fields of agricultural science, hydrogeology and mining and petroleum development. ${ }^{81}$ Prior to determining an application for a gateway certificate, the Gateway Panel must refer the application to the Independent Expert Scientific (IES) Committee, ${ }^{82}$ and the Minister for Primary Industries for advice. ${ }^{83}$ The advice of the IES Committee and Minister for Primary Industries must have regard to the minimal impact considerations set out in the Aquifer Interference Policy. ${ }^{84}$

In determining applications for gateway certificates, the Gateway Panel must take account of several 'relevant criteria'. ${ }^{85}$ The fundamental tenet is that the proposed development will not 'significantly reduce the agricultural productivity' of any BSAL. ${ }^{86}$ There are many criteria listed for consideration, including impacts on the land through surface area disturbance and subsidence; impacts on soil fertility, effective rooting depth or soil drainage; increases in micro-relief, salinity, rockiness, or significant changes in soil $\mathrm{pH}$; impacts on highly productive groundwater; fragmentation of agricultural landuses; and reduction in the area of BSAL. Similarly, in relation to critical industry cluster land, the fundamental principle to be applied is that the proposed development will not have a significant impact on the relevant critical industry. ${ }^{87}$ Criteria to be considered include: impacts on land surface disturbance and subsidence; reduced access to or impacts on water and agricultural resources; reduced access to support services and infrastructure; reduced access to transport routes; and the loss of scenic and landscape values. In each case the Gateway Panel, in determining whether a proposed development meets the relevant criteria, is to have regard to the duration of any impacts, as well as any proposed 'avoidance, mitigation, offset or rehabilitation measures' in relation to any impacts. ${ }^{88}$

Following consideration of the relevant criteria, as well as seeking any additional information from applicants, ${ }^{89}$ the Gateway Panel may either issue an 'unconditional certificate' that states the proposed development meets the relevant criteria, or a 'conditional certificate' that effectively states that the proposed development does not meet the relevant criteria. ${ }^{90}$ In issuing a conditional certificate, the panel is to include recommendations to address the proposed development's failure to meet the relevant criteria, and may also include a recommendation that specified or further studies be undertaken. ${ }^{91}$ Gateway certificates remain current for up to five years. ${ }^{92}$ Many community members have expressed concerns about some exploration activities, ${ }^{93}$ so a further initiative of the NSW Government has been the appointment, in 2012, of a Land and Water Commissioner. The Commissioner's role is to provide independent advice to the community regarding exploration activities on Strategic Agricultural Land throughout the state and to build community confidence in the processes governing exploration activities in NSW by facilitating greater consultation between government, community and industry. ${ }^{94}$

\footnotetext{
77 Environmental Planning and Assessment Regulation 2000 (NSW) cl 50A.

${ }^{78}$ The Director-General is now referred to as the Secretary.

79 SEPP (Mining, Petroleum Production and Extractive Industries) 2007 (NSW) cl $17 \mathrm{C}$.

Ibid cl 17F.

${ }^{81}$ NSW Government, Mining \& Petroleum Gateway Panel (2014)

<http: / / www.mpgp.nsw.gov.au/?action=page\&page=members $>$

82 Independent Expert Scientific Committee on Coal Seam Gas and Large Coal Mining Development established by the Environment Protection and Biodiversity Conservation Act 1999 (Cth).

${ }^{83}$ SEPP (Mining, Petroleum Production and Extractive Industries) 2007 (NSW) cl $17 \mathrm{G}$.

${ }^{84}$ A component of the Strategic Regional Landuse Policy. NSW Government, September 2012.

${ }^{85}$ SEPP (Mining, Petroleum Production and Extractive Industries) 2007 (NSW) cl 17H(4).

${ }^{86}$ lbid $\mathrm{Cl} 17 \mathrm{H}(4)(\mathrm{a})$.

${ }^{87}$ lbid $\mathrm{cl} 17 \mathrm{H}(4)(\mathrm{b})$

88 Ibid $\mathrm{cl} 17 \mathrm{H}(5)$.

99 lbid $\mathrm{cl} 17 \mathrm{~J}(1)$.

90 Ibid $\mathrm{cl} 17 \mathrm{H}(2)$.

91 lbid $\mathrm{Cl} 17 \mathrm{H}(3)$.

92 Ibid cl $17 \mathrm{~K}$

${ }^{93}$ Hanabeth Luke et al., 'Unconventional Gas Development: Why a Regional Community Said No' (2014) 52 Geographical Research 263, DOI: 10.1111/1745-5871.12071.

${ }^{94}$ NSW Government, Land and Water Commissioner Fact Sheet (2013) <https://www.nsw.gov.au/sites/default/files/landandwatercommissioner-factsheet_update_19-march-2013.pdf>.
} 
A further application of the SEPP is to regulate the 'winning' of soil itself as soil is defined as an 'extractive material'. ${ }^{95}$ Effectively, the extraction of soil from land that is zoned for the purposes of agriculture or industry may be carried out with appropriate development consent. ${ }^{96}$ Note that under LEPs, such as for the Liverpool Plains, extractive industries are permitted in certain landuse zones, including land zoned for Primary Production, but, again, only with development consent from the relevant authority. ${ }^{97}$

The governance of productive soils in NSW with respect to competing landuses, such as mining, petroleum exploration and extractive industries is well advanced and prima facie largely utilises regulation, enforcement and compliance, and assessment procedures embedded in planning instruments, natural resource management legislation and related policies. However, the decision of the NSW government to create an independent advisory role in the form of the Land and Water Commissioner is an example of an institutional arrangement, and extension being used to better enable other policies, and allowing information exchange between industry, agency and community stakeholders. It should be noted, however, that despite the existence of these governance mechanisms, in some areas, there remains community concern regarding the co-existence of mining, petroleum exploration and agricultural production. ${ }^{98}$

\section{Managing diffuse source pollution}

Traditionally, diffuse or non-point sources of pollution have been difficult to regulate and, in NSW, they were largely not considered until the introduction of the Protection of the Environment Operations Act 1997 (NSW). The world leader in the management of non-point source pollution has been the government of the US, particularly the US EPA following the passage of the Water Pollution Control Act 1972. ${ }^{99}$ While acknowledging that primary industries, particularly agriculture, are the main sources of non-point source pollution, much of the headway in managing land-derived pollution has occurred on US Federal Lands such as the National Forest Estate. ${ }^{100}$ According to the Organic Act that established the US Forest Service in 1897 'No national forest shall be established, except to improve and protect the forest within the boundaries, or for the purpose of securing favorable conditions of water flows'. ${ }^{101}$ In this respect, the US Government acknowledged, even in the $19^{\text {th }}$ century, the value of ground- and forest-cover in reducing soil erosion and thereby protecting water supplies. ${ }^{102}$ The situation across Australia, and specifically in NSW, was rather different because NSW government initiatives to establish State Forests and Crown timber lands were not motivated by soil conservation and watershed protection. The original Forestry Act 1916 (NSW) ${ }^{103}$ that established the Forestry Commission of NSW did not mention 'soil' in any context. It was not until 1972 that section 8 A was added to the Act and, among other things, listed an objective of the Commission to be:

to preserve and improve, in accordance with good forestry practice, the soil resources and water catchment capabilities of Crown-timber lands and land owned by the commission or otherwise under its control or management.

In 2013 the Forestry Commission of NSW was converted into a state-owned corporation and preserving soil and water resources is no longer one of the legislated objectives of the Forestry Corporation. ${ }^{104}$ However, the corporation's environmental obligations remain embedded within existing regulatory frameworks. For example, following the Regional Forest Agreement (RFA) process during the 1990s, significant areas of native state forest became National Parks and, as such, were 'protected' from the potential effects of silvicultural management. ${ }^{105}$ On the remaining State Forests, timber harvesting is allowed subject to the conditions of Integrated Forestry Operations Approvals (IFOAs). ${ }^{106}$ With regard to soil and water values, the principal

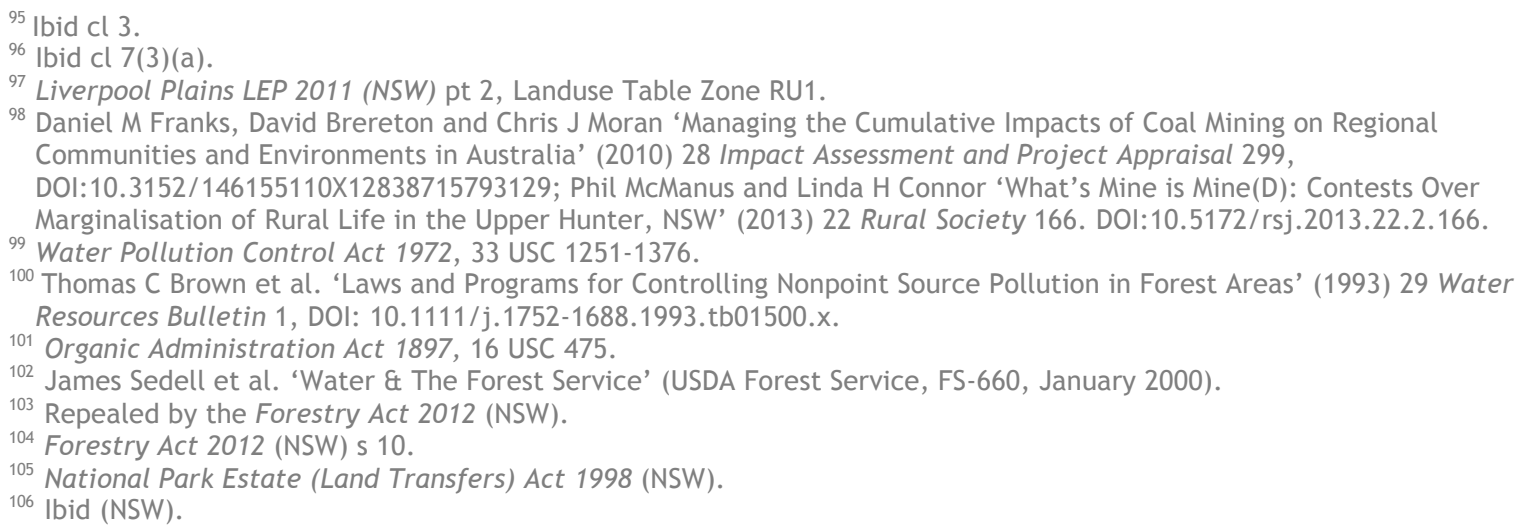


instruments are the Environment Protection Licences (EPLs) issued by the EPA as appendices to the IFOAs. ${ }^{107}$ These 'pollution licences', as applied to non-point sources, in many ways, are ground-breaking in NSW, as formerly they applied to 'scheduled activities' which were almost exclusively point sources of pollution. ${ }^{108}$ The object of each licence is to require practical measures to be taken to protect the aquatic environment from water pollution, which, in a forestry context, derives from soil erosion and sediment delivery to drainage features. ${ }^{109}$ Similar measures are required under the Plantations and Reafforestation (Plantations Code) Regulation 2001 (NSW) that applies to plantation forestry.

The conditions and practical measures contained within the forestry EPLs and Plantations Code include a range of Best Management Practices (BMPs) that were largely developed by the industry based on research outcomes. ${ }^{110}$ Some of the BMPs include: soil conservation measures for the design of bridges, culverts and causeways; appropriate drainage spacings on roads and skid tracks; seasonal harvesting restrictions; slope restrictions for harvesting and road construction activities; wet weather restrictions on the use of roads and log landings; mass movement hazard conditions; soil dispersibility conditions; and protection of drainage features by the use of filter strips and/or buffer strips. Arguably, these measures contained within the EPLs and Plantations Code have been very effective in reducing the effects of forestry activities on soil erosion and off-site water quality. ${ }^{111}$

While significant effort had been devoted to regulating nonpoint sources of soil or sediment-derived pollution on the public forest estate, until a few years ago there was no coordinated approach to such regulation or management across other land tenures. In June 2009 the NSW Government published a diffuse source water pollution strategy, which has the following primary objectives:

- To identify new and effective ways of achieving state-wide collaboration by focusing on actions that address priority diffuse source water pollution problems;

- To prioritise management actions to guide investment decisions and focus efforts; and

- To provide an agreed framework to promote and report on the implementation of priority management action plans and partnerships. ${ }^{112}$

The strategy deals with not only diffuse sources of sediment but also nutrients, toxicants and pathogens. It sets out some principles for a coordinated approach to land and water management to reduce pollution for the various agencies involved including the EPA, ${ }^{113}$ Department of Planning, ${ }^{114}$ local councils, ${ }^{115}$ and the DPI - Soil Conservation Service. ${ }^{116}$

Nonpoint source pollution is difficult to manage and regulate, particularly across diverse landscapes and multiple land tenures. However, the forestry reforms highlight the benefits of incorporating industry BPM in regulatory instruments while the NSW Diffuse Source Water Pollution Strategy establishes useful frameworks for coordinated land and water management. While the governance focus of the diffuse source pollution laws is ostensibly regulation, enforcement and compliance, other models are embedded within the regulatory framework. These include self-regulation, because industry has contributed to: codes of practice; R\&D, which leads to the development of BMPs; as well as monitoring and evaluation, which is strongly embedded within the forestry EPLs and IFOAs.

\section{Managing acid sulfate soils: The benefit of industry-specific guidelines}

Potential acid sulfate soils (ASS), comprising iron disulphides (iron pyrite) in waterlogged soil layers, commonly occur in coastal zones around Australia. Many activities, including construction of flood mitigation drains and floodgates, dredging, road construction or cultivation that are typically associated with sugarcane production,

\footnotetext{
107 Protection of the Environment Operations Act 1997 (NSW) ch 3.

108 Ibid sch 1.

109 Jacky Croke and Peter Hairsine, 'Sediment Delivery in Managed Forests: A Review' (2006) 14 Environmental Reviews 59, DOI: $10.1139 / \mathrm{a} 05-016$

${ }^{110}$ Ashley A Webb 'Can Timber and Water Resources be Sustainably Co-Developed in South-Eastern New South Wales, Australia?’ (2012) 14 Environment, Development and Sustainability 233. DOI: 10.1007/s10668-011-9319-3

${ }^{111}$ Ashley A Webb et al. 'Temporary Increases in Suspended Sediment Yields Following Selective Eucalypt Forest Harvesting' (2012) 283 Forest Ecology and Management 96, DOI: 10.1016/j.foreco.2012.07.017.

${ }^{112}$ NSW Department of Environment and Climate Change, NSW Diffuse Source Water Pollution Strategy (June 2009) 5.

${ }^{113}$ Protection of the Environment Operations Act 1997 (NSW) s 120

${ }^{114}$ Environmental Planning and Assessment Act 1979 (NSW) s 79C.

${ }^{115}$ Local Government Act 1993 (NSW) s 68.
}

${ }^{116}$ Soil Conservation Act 1938 (NSW) s 4C. 
can expose these soils to air, causing oxidation of the pyrite to produce sulphuric acid. Under this scenario, the soils are termed Actual Acid Sulfate Soils and the release of sulphuric acid has severe consequences for water quality, not only causing acidity but also producing toxic concentrations of dissolved aluminium and iron. The implications for aquatic organisms, including fish and oysters, are often catastrophic, and the release of acid water has significant negative implications for cropping and grazing. ${ }^{117}$ While managing these soils has largely been associated with coastal farming activities, such as sugarcane production, it is also well established that ASS can occur inland, especially where mineral sulphides have accumulated within the sediments of freshwater wetlands. ${ }^{118}$

The sugar industry in NSW operates on 35000 hectares of the lower Tweed, Richmond, Brunswick and Clarence River floodplains, half of which is underlain by ASS. In response to a major fish kill in 1987, along with growing research into ASS, the sugar industry had 'taken control' of the issue on canelands by $1996 .{ }^{119}$ Industry initiatives included undertaking and supporting research and extension, a five-year project to sample ASS on nearly all NSW cane farms, and the development of guidelines for drain construction and maintenance on ASS in conjunction with the NSW EPA. ${ }^{120}$ The guidelines aim to: minimise the export of acidity from cane farms; minimise any downstream environmental impacts caused by acid export; maximise production from cane land; and ensure compliance with relevant legislative provisions and statutory plans, including LEPs. They establish information on the depth, location and nature of ASS, as well as the location and dimensions of existing, new or redesigned drains that must provide efficient drainage without creating an acid hazard. They also indicate liming rates for spoil and drain water. The guidelines outline appropriate management strategies for drain and floodgate maintenance, along with the establishment of audit and compliance procedures. ${ }^{121}$

In 1998 the (then) NSW Department of Urban Affairs and Planning (DUAP) advised the industry that planning provisions would be introduced and also published guidelines that outline best practice in assessing the possible impacts of proposed activities in areas likely to contain ASS. ${ }^{122}$ The guidelines are intended to apply to various activities including: the excavation or disturbance of ASS; lowering of the water table; and the use of ASS, such as in earthworks or landfill. They establish standard methods for preliminary assessments to: determine if ASS are present; design soil assessment and monitoring programs; design water assessment programs; establish methods for managing ASS; and establish approaches to checking and approving development applications. The majority of local councils in coastal regions of NSW have now incorporated the management of ASS into planning instruments, such as LEPs. For example, an objective within the Tweed LEP is to ensure that development does not disturb, expose or drain ASS and cause environmental damage. ${ }^{123}$ In the LEP, ASS are mapped, and development consent is required for works classified into any of five classes; these are determined by the depth below the natural ground surface and the impact of the work on the level of the water table. Any works are only to be granted development consent if an ASS management plan has been prepared for the proposed works in accordance with the Acid Sulfate Soils Manual, and only if the plan has been provided to the consent authority. ${ }^{124}$ There are, as expected, some exceptions to these requirements, such as if a public authority is carrying out emergency work or routine maintenance work involving the disturbance of less than one tonne of soil. ${ }^{125}$

Given the sugar industry's active engagement in the development of Best Practice Guidelines, the NSW Sugar Milling Cooperative Ltd sought exemption from the consent process in relation to ASS, preferring to selfregulate. ${ }^{126}$ This has been accepted and today the industry is exempt from certain consent requirements under the Tweed, ${ }^{127}$ Byron, ${ }^{128}$ Lismore, ${ }^{129}$ Ballina, ${ }^{130}$ Richmond Valley, ${ }^{131}$ and Clarence Valley LEPs, ${ }^{132}$ which cover the

\footnotetext{
117 Jes Sammut et al. 'Acidification of an Estuarine Tributary in Eastern Australia Due to Drainage of Acid Sulfate Soils' (1996) 47 Marine and Freshwater Research 669, DOI:10.1071/MF9960669.

${ }^{118} \mathrm{~K}$ C Hall et al. 'Distribution of Inland Wetlands with Sulfidic Sediments in the Murray-Darling Basin, Australia' (2006) 370 Science of the Total Environment 235, DOI.org/10.1016/j.scitotenv.2006.07.019.

${ }^{119}$ R N Beattie et al. 'Achieving Self-Regulation for Drain Maintenance in the NSW Sugar Industry' (2001) 23 Proceedings Australian Society Sugar Cane Technology 51, 52

120 Ibid.

${ }^{121}$ Sunshine Sugar, The NSW Sugar Industry Best Practice Guidelines for Acid Sulfate Soils (March, 2005).

122 Acid Sulfate Soil Management Advisory Committee, Acid Sulfate Soils Assessment Guidelines (1998).

123 Tweed LEP 2014 (NSW) cl 7.1(1).

124 Ibid cl 7.1(3).

125 Ibid cl 7.1(5-6).

${ }^{126}$ Beattie, above n 119, 53

127 Tweed LEP 2014 (NSW).

128 Byron LEP 2014 (NSW).

129 Lismore LEP 2012 (NSW).

130 Ballina LEP 2012 (NSW).

${ }^{131}$ Richmond Valley LEP 2012 (NSW).
} 
extent of sugarcane farming in NSW. With regard to the conduct of works for the purposes of agriculture, development consent is not required if a 'production area entitlement' is in force on the land where the work is to be carried out and where certain conditions are met. ${ }^{133}$ A production area entitlement is a contract between the NSW Sugar Milling Co-operative Limited and a grower member of that co-operative for the production of sugar cane for milling. The conditions that need to be met include that the works: are not being carried out with respect to any major drains identified on the ASS Map; ${ }^{134}$ are not being carried out on land classed as coastal wetlands; ${ }^{135}$ and are carried out in accordance with a 'drainage management plan' ${ }^{136} \mathrm{~A}$ drainage management plan is prepared in accordance with the NSW Sugar Industry Best Practice Guidelines for Acid Sulfate Soils, ${ }^{137}$ and is endorsed by the Sugar Milling Co-operative as being appropriate for the land. ${ }^{138}$

The governance and management of ASS utilises R\&D, extension, self-regulation, formal agreements, covenants and memoranda of understanding to complement regulation, enforcement and compliance. It is a sound example of an agricultural industry taking ownership of an environmental and soils management problem, and working constructively with regulatory and consent authorities to find workable solutions and responsible outcomes that maintain the industry's profitability and sustainability.

\section{Catchment-scale land and vegetation management}

Integrated catchment management or total catchment management has been mentioned in NSW government policy for some time and, as stated above, the Hunter Valley Conservation Trust Act 1950 (NSW) was one of the early initiatives to establish soil conservation efforts at the catchment scale. Non-government organisations have also been espousing these principles for several decades. For example, the Landcare Network provides an invaluable contribution to integrated natural resource management. ${ }^{139}$ It is a wellestablished example of grass-roots extension.

More recently, Cryptosporidium and Giardia, two major causes of gastrointestinal illness, ${ }^{140}$ were detected in Warragamba Dam and throughout the Sydney Water Corporation's supply system between July and September 1998. ${ }^{141}$ Given the potential seriousness of such an outbreak for public health, ${ }^{142}$ the NSW Government commissioned a comprehensive inquiry into the management of Sydney's water supply. ${ }^{143}$ Following one of the many recommendations of the inquiry, the Sydney Catchment Authority (SCA) was promptly established as a statutory body representing the Crown. ${ }^{144}$ The role of the SCA is threefold: manage and protect Sydney's catchment areas and infrastructure works; supply raw water to Sydney Water and other water authorities; ${ }^{145}$ and regulate certain activities within or affecting the 'inner' or 'outer' catchment. ${ }^{146}$ In fulfilling this role, the SCA is to ensure that it promotes water quality, protects public health, safety and the environment, supplies water that meets appropriate quality standards, and that its operations are consistent with the principles of ecologically sustainable development. ${ }^{147}$ The SCA is granted the same functions as the EPA across the entire catchment area $^{148}$ to investigate matters, serve environment protection notices and undertake proceedings for

${ }^{132}$ Clarence Valley LEP 2011 (NSW).

${ }^{133}$ Tweed LEP 2014 (NSW) cl 7.1(7).

134 Ibid $\mathrm{Cl} 7.1(2)$.

135 State Environmental Planning Policy No 14 - Coastal Wetlands (NSW).

136 Tweed Local Environmental Plan 2014 (NSW) cl 7.1(7b).

137 Sunshine Sugar, above n 122.

${ }^{138}$ Tweed LEP 2014 (NSW) cl 7.1(8).

139 Landcare Australia Limited, Landcare Australia: Everyone, Everywhere, Landcare (2014) <http://www.Landcareonline.com.Au/>.

140 Josephine Ng et al., ‘Identification of Zoonotic Cryptosporidium and Giardia Genotypes Infecting Animals in Sydney's Water Catchments’ (2011) 128 Experimental Parasitology 138 DOI: 10.1016/j.exppara.2011.02.013.

${ }^{41}$ P L Stein, 'The Great Sydney Water Crisis of 1998' (2000) 123 Water, Air, and Soil Pollution 419, DOI:10.1023/A:1005255202854.

${ }^{142}$ Neil J Hoxie et al., 'Cryptosporidiosis-Associated Mortality Following a Massive Waterborne Outbreak in Milwaukee, Wisconsin' (1997) 87 American Journal of Public Health 2032 DOI: 10.2105/AJPH.87.12.2032; William R Mackenzie et al., 'A Massive Outbreak in Milwaukee of Cryptosporidium Infection Transmitted Through the Public Water Supply' (2004) 33 The New England Journal of Medicine 161, DOI: 10.1056/NEJM199407213310304.

${ }^{143}$ Peter McClellan, 'Sydney Water Inquiry Final Report' (NSW Premier's Department, December 1998).

144 Sydney Water Catchment Management Act 1998 (NSW) s 6.

145 Ibid.

146 Ibid s 13

147 Ibid s 14

148 Sydney Water Catchment Management Regulation 2008 (NSW) s 4. 
offences in relation to non-scheduled activities. ${ }^{149}$ This is clearly a regulation, enforcement and compliance role.

Another of the SCA's regulatory functions is to carry out a concurrence role in relation to environmental planning within the catchments. ${ }^{150}$ All development or activity proposed within the catchments must comply with the SCA's recommended practices and standards, ${ }^{151}$ and the SCA Chief Executive must agree with the consent. ${ }^{152}$ In theory all development within the catchments is to have a 'neutral or beneficial effect' on water quality before the SCA will grant concurrence. ${ }^{153}$ With respect to broader soil and land management, the SCA has developed a decision support system to identify the greatest risks to pollution within the catchments. ${ }^{154}$ The decision support system has guided catchment actions to be strategically undertaken to improve water quality. ${ }^{155}$ During the 2010-2011 financial year the SCA spent $\$ 20.45$ million on its "Healthy Catchments' program involving a range of tasks from fencing stock out of riparian zones, to the rehabilitation of derelict mines and repairing sites of streambank and gully erosion. ${ }^{156}$ This is a working example of direct investment as a governance mechanism to deliver specific on-ground outcomes.

While the Sydney catchment reforms were targeted at a drinking water supply, it was recognised early in the $21^{\text {st }}$ century that significant reforms were required at a state- and catchment-wide level if agricultural practices were to be more sustainable and contribute to restoring landscapes to support rural communities as well as viable food and fibre production. A key group of Australia's leading environmental scientists, dubbed 'the Wentworth Group', advocated radical and fundamental reform to halt further degradation of Australia's landscapes by publishing the first of a series of 'Blueprints', in which they recommended a model of regional catchment-level management. ${ }^{157}$ The NSW Government had been progressing with such reforms already and moved swiftly to implement many of The Wentworth Group's recommendations, including native vegetation reforms, ${ }^{158}$ establishment of the Natural Resources Commission, ${ }^{159}$ and Catchment Management Authorities. ${ }^{160}$ Each is briefly outlined below.

The objectives of the Native Vegetation Act 2003 (NSW), which are relevant to soils governance, are: to encourage and promote the management of native vegetation on a regional basis; to prevent broad scale clearing unless it improves or maintains environmental outcomes; to protect native vegetation of high conservation value having regard to its contribution to matters including prevention of salinity or land degradation; to improve the condition of existing native vegetation; and to encourage the revegetation of land, and the rehabilitation of land, with appropriate native vegetation. ${ }^{161}$ One of the key requirements of the Act is that native vegetation must not be cleared unless it is in accordance with a development consent, ${ }^{162}$ or an approved property vegetation plan. ${ }^{163}$ Property vegetation plans are essentially a legally binding agreement between a landowner and the Minister or their delegate such as Local Land Services (formerly Catchment Management Authorities). ${ }^{164}$ The management of native vegetation thus combines elements of regulation, enforcement and compliance with formal agreements.

When the Catchment Management Authorities Act 2003 (NSW) came into effect it established 13 Catchment Management Authorities (CMAs) in NSW as statutory bodies representing the Crown controlled by boards with collective skills and knowledge in several areas of natural resources management. ${ }^{165}$ Each CMA effectively provided for proper natural resource management at a catchment level, involved communities in decisionmaking and applied sound scientific knowledge to achieve a 'fully functioning and productive landscape'. ${ }^{166}$

\footnotetext{
${ }^{149}$ Protection of the Environment Operations Act 1997 (NSW) Chs 4, 7, and div 2 of pt 8.2.

150 Sydney Water Catchment Management Act 1998 (NSW) s 17; Environmental Planning and Assessment Act 1979 (NSW) Div 1 A of Pt 6.

151 Sydney Catchment Authority, Developments in Sydney's Drinking Water Catchment: Water Quality Information Requirements (2011).

152 State Environmental Planning Policy (Sydney Drinking Water Catchment) 2011 (NSW) ss 9, 11.

153 Ibid s 10.

154 Sydney Catchment Authority, Prioritising Catchment Actions - The Catchment Decision Support System 2009-2010 (2009).

${ }^{155}$ Sydney Catchment Authority, Healthy Catchments Strategy 2009-2012 (2009).

${ }^{156}$ Sydney Catchment Authority, Healthy Catchments Program 2010-2011 (2011).

157 The Wentworth Group, Blueprint for a Living Continent, (1 November 2002).

${ }^{158}$ Native Vegetation Act 2003 (NSW).

159 Natural Resources Commission Act 2003 (NSW).

${ }^{160}$ Catchment Management Authorities Act 2003 (NSW) repealed by Local Land Services Act 2013 (NSW).

${ }^{161}$ Native Vegetation Act 2003 (NSW) s 3.

${ }^{162}$ Environmental Planning and Assessment Act 1979 (NSW) Pt 4.

163 Native Vegetation Act 2003 (NSW) s 12(1).

164 Ibid s 48.

${ }^{165}$ Catchment Management Authorities Act 2003 (NSW) s 8.

166 lbid s 3.
} 
Each of the CMAs used catchment action plans as a basis for assistance to landholders through grants, loans, subsidies, and education and training courses. In 2014 the CMAs were replaced with some functions integrated into 11 Local Land Services (LLS). Each LLS is a regional organisation with 'responsibility for management and delivery of local land services in the social, economic and environmental interests of the State' ${ }^{167}$ The LLSs are governed by independent local boards and, in the interim, any Catchment Action Plan in place continues to have effect in respect of natural resource management (within the meaning of the former CMA Act) of the land to which it applied immediately before the repeal date. This arrangement will continue until it is superseded by a local strategic plan containing provisions with respect to natural resource management. ${ }^{168}$ The establishment of LLSs in NSW has transitioned the end-user advisory role, previously the remit of DPI Agriculture, to LLS. This change is in accordance with the Act that prescribes that 'local land services means programs and advisory services associated with agricultural production, biosecurity, natural resource management and emergency management'. ${ }^{169}$ This means that many former agricultural extension functions, such as those relating to soil science, are now to be situated within LLSs. While it is within the powers of LLS to enter into a memorandum of understanding with government departments with respect to the delegation of its functions, this had not happened, to the authors' knowledge, at the time of writing. ${ }^{170}$ The LLSs and former CMAs use a combination of governance mechanisms or models such as direct investment, extension, formal education and training, economic incentives, and monitoring and evaluation.

Finally, the Natural Resources Commission (NRC) was established as an independent body to: establish a sound scientific basis for the properly-informed management of natural resources; enable the adoption of state-wide standards and targets for natural resource management issues; and advise on the circumstances in which broad scale clearing is to be regarded as improving or maintaining environmental outcomes for the purposes of the Native Vegetation Act 2003 (NSW). ${ }^{171}$ In addition, the Commission has played a key role in auditing many aspects of natural resources management implementation in NSW, such as the implementation of catchment action plans, and advises the NSW government on priority areas for investment in natural resources research and development. ${ }^{172}$ The NRC, therefore, utilises governance mechanisms including institutional arrangements, assessment procedures, and regulation, enforcement and compliance.

In summary, significant reforms in the last decade have progressed former aspirations for total catchment management and embedded them within appropriate legislative and institutional frameworks that utilise a raft of governance mechanisms.

\section{The role of research and development in underpinning governance}

While the governance structures described in the above sections provide for frameworks that encourage and promote profitable and sustainable use of the state's productive agricultural soils, appropriate outcomes could not be achieved without adequate knowledge that informs wise management and underpins policy. ${ }^{173}$ Significant gains in productivity observed since the 1950s have been attributed to substantial investment in agricultural R\&D. ${ }^{174}$ The initiation of the SCS in 1938 acknowledged the need for governance to be underpinned by R\&D. Hence there was a substantial investment in the establishment of research stations in the early years of the SCS, as previously discussed. The continuing need for governance to be underpinned by knowledge was highlighted by Campbell in $2008^{175}$ and, more recently, the state and Commonwealth governments have developed a National Strategy for Soil Research, Development and Extension ('National RD\&E Strategy'), ${ }^{176}$ which aims to:

- $\quad$ Ensure the national soil RD\&E system generates and applies new knowledge to meet future challenges in soil use and management;

\footnotetext{
${ }^{167}$ Local Land Services Act 2013 (NSW) s 3(a).

${ }^{168}$ Ibid sch 6(10).

${ }^{169}$ Ibid s 4(1).

170 Ibid s 15

171 Natural Resources Commission Act 2003 (NSW) s 3.

172 Ibid s 13.

${ }^{173}$ A Campbell, 'Managing Australia's Soils: A Policy Discussion Paper Prepared for the National Committee on Soil and Terrain' (CSIRO, 2008).

${ }^{174} \mathrm{G}$ Stoneham, M Eigenraam, A Ridley \& N Barr 'The Application of Sustainability Concepts to Australian Agriculture: An Overview' (2003) 43 Australian Journal of Experimental Agriculture 195, DOI.org/10.1071/EA00173.

${ }^{175}$ Campbell, above $\mathrm{n} 173$.

${ }^{176}$ Commonwealth of Australia, The National Soil Research, Development and Extension Strategy, Securing Australia's Soil, For profitable industries and healthy landscapes (2014).
} 
- Develop a process for national coordination and prioritisation of investment in soil RD\&E to increase both effectiveness and efficiency, and commence the actions necessary to implement it;

- Improve the quality, availability and access to soil data and soil management information to meet user needs;

- Facilitate effective transfer of soil data, information and knowledge to end users;

- $\quad$ Assess future national soil RD\&E capability needs and steps required to provide that capability (including education, training, people and skill development and RD\&E infrastructure); and

- Encourage greater collaboration in developing and using physical infrastructure and human resources. ${ }^{177}$

The Strategy outlines future research directions, including: improving soil management to increase agricultural productivity and profitability; quantifying soil assets in space and time via mapping, modelling, monitoring and forecasting; finding solutions to manage soil/subsoil constraints; understanding soil and its role in delivering ecosystem services; managing soil across the landscape; harvesting, verifying and communicating innovations in soil management; and capturing bright ideas to deliver world-class outcomes. ${ }^{178}$

In NSW, $\$ 27$ million is invested in soil R\&D annually, $\sim \$ 15 M$ of which is managed by government agencies including DPI Agriculture and the OEH. ${ }^{179}$ NSW DPI is the single largest provider of soil R\&D in the state. Within the context of the National RD\&E Strategy, and aligned with the governance structures in NSW, including the advisory services in LLS, the DPI Agriculture Soils Unit develops and promotes technologies and management systems that improve soil physical, chemical and biological productivity, protect the soil resource, build resilience and reduce adverse environmental impacts. The Unit's program provides new and improved management options and data-driven evidence to inform policy and planning and to ensure the sustainable use, management and conservation of the state's soil assets. NSW DPI collaborates with industry, government, RD\&E bodies and communities to foster sustainable soil use, management and conservation.

Identifying links between key policy areas and soil R\&D is fundamental when addressing contemporary issues such as increasing primary production to assist global food security, a changing and variable climate, and sustainable development. The research, development and policy expertise of agencies, such as DPI and OEH, is utilised to ensure that legislation, policy and planning are underpinned by sound technical knowledge to enable the sustainable, evidence-based management of the soil resource. The return on R\&D investment is large. However the focus of this return on investment is largely in a production context and it is difficult to directly quantify the benefit of R\&D to governance. Needless to say, developments in policy and governance should be guided by the best available knowledge, which arises out of R\&D and soil condition monitoring.

\section{Conclusions}

Governance of soil and, indeed, management perspectives, have changed in NSW since Federation in 1901 when soils and other natural resources were barely considered by the framers of the Australian Constitution. Following a period of rapid agricultural development and in the face of widespread soil degradation, the establishment of the Soil Conservation Service marked a turning point for soils research and management in NSW. Throughout the $20^{\text {th }}$ century substantial advancements in knowledge were translated into evolving legislative frameworks that were largely reactionary, but saw progressive reforms such as water pollution legislation and case studies of catchment-scale land and vegetation management.

In the $21^{\text {st }}$ century significant reforms in soil governance have occurred in NSW that have embedded sustainable use of agricultural soils within catchment- and landscape-scale legislative and institutional frameworks. Planning instruments largely recognise the threats to agricultural soils and have been drafted to protect productive soil from sub-division threats; and competition from competing landuses such as mining, petroleum exploration and extractive industries. Primary industries have been involved in the regulation and management of off-site impacts caused by activities such as forestry and the disturbance of acid sulfate soils.

A multitude of governance models are utilised in NSW, including regulation, enforcement and compliance, direct investment, formal agreements, research and development, monitoring and evaluation, extension,

\footnotetext{
177 Ibid ii.

178 Ibid.

179 Department of Agriculture, Fisheries and Forestry, A stocktake of Australia's Current Investment in Soils Research, Development and Extension: A Snapshot for 2010-11 (2011).
} 
assessment procedures, self-regulation, formal education and training, economic incentives, and institutional arrangements. No single governance model is currently applicable to all situations and it appears necessary to combine elements of several different mechanisms or instruments to achieve the most desired outcomes. Where an industry such as the sugar industry has taken ownership of an issue, such as acid sulfate soils, selfregulation has proven to be extremely effective. In the case of co-managing agricultural soils with other landuses, such as mining, petroleum exploration or urban development, regulation, compliance and enforcement mechanisms such as planning instruments, have been preferred. Institutional arrangements in the form of independent commissioners have also played a role. At the landscape or total catchment level it is clear that a mix of mechanisms is required, as exemplified by the Local Land Services that utilise direct investment, extension, formal education and training, economic incentives, and monitoring and evaluation governance models and strategies.

However, fundamental to the successful evolution of all existing models, and future revitalised models of soils governance, is strategic investment in soils research and development that informs the ongoing productive use of agricultural landscapes while preventing land degradation or adverse environmental effects. 